Sains Malaysiana 50(10)(2021): 2923-2936

http://doi.org/10.17576/jsm-2021-5010-07

\title{
Essential Oil and Leaves from Lantana camara Significantly Ameliorate Different Cancer Cell Lines by Suppressing the NF-אB Pathway
}

(Minyak Pati dan Daun daripada Lantana camara secara Signifikan Memperbaiki Garis Sel Kanser Berbeza dengan Merencat Laluan NF- $\kappa \mathrm{B}$ )

\author{
ArfaA Sajid, QAisar Manzoor, Anam Sajid, Rabia Shabir Ahmad, Ghulam Hussain, Muhammad Imran, \\ Farhan Aslam, MuHAmmad Umair Arshad, TANWEer Aslam GONDAL \& Ali IMran*
}

\section{ABSTRACT}

The anticancer and anti-inflammatory activities of wild-sage (Lantana camara) leaves essential oil were evaluated against various human cell lines. In this regard, steam hydro-distillation technique was used for oil extraction. Chemical characterization of L. camara essential oil (LCEO) was done by GC-MS, and forty one chemical components (98.69\%) were detected in leaves of LCEO. The major constituents were caryophyllene oxide (19.63\%), caryophyllene (6.68\%), $\beta$-phellandrene (6.48\%), humulene epoxide II (5.68\%), spathulenol (4.17\%), $\alpha$-pinene (3.27\%), eucalyptol (3.09\%), $\alpha$-cyclocitral (2.89\%), $\beta$-pinene (2.38\%), and nerolidol II (2.33\%). Moreover, the antioxidant and antimicrobial potential of LCEO were also examined. LCEO also showed good anti-inflammatory activity. Interestingly, it was found that the L. camara essential oil was active against a set of microbial strains along with promising antioxidant activity. The MTT assay showed that LCEO possessed good anticancer potential against U-266, A-549, HCT-116, SCC-4, MiaPaCa 2, and KBM-5 cancer cell lines. In these cell lines, it was depicted that the LCEO blocked the tumor cell proliferation via $N F-\kappa B$ pathway suppression. The promising and potent bioactivities of LCEO support the candidature of these essential oils as an anticancer agent.

Keywords: Anti- inflammatory; GC-MS; Lantana camara; MTT assay

ABSTRAK

Aktiviti antikanser dan anti-radang minyak pati daun liar (Lantana camara) dinilai berdasarkan pelbagai titisan sel manusia. Dalam hal ini, teknik penyulingan hidro wap digunakan untuk pengekstrakan minyak. Pencirian kimia minyak pati L. camara (LCEO) dijalankan melalui GC-MS dan empat puluh satu komponen kimia (98.69\%) dikesan pada daun LCEO. Konstituen utama adalah kariofilin oksida (19.63\%), kariofilin (6.68\%), $\beta$-fellandren (6.48\%), humulena epoksida II (5.68\%), spathulenol (4.17\%), $\alpha$-pinene (3.27\%), eucalyptol (3.09) \%), $\alpha$-siklokitral (2,89\%), $\beta$-pinena (2,38\%) dan nerolidol II (2,33\%). Selain itu, potensi antioksidan dan antimikrob LCEO juga dikaji. LCEO juga menunjukkan aktiviti anti-radang yang baik. Menariknya, didapati bahawa minyak pati L. camara aktif melawan sekumpulan strain mikrob dengan potensi aktiviti antioksidan. Ujian MTT menunjukkan bahawa LCEO memiliki potensi antikanser yang baik terhadap barisan sel barah U-266, A-549, HCT-116, SCC-4, MiaPaCa 2 dan KBM-5. Dalam garis sel ini, digambarkan bahawa LCEO menyekat percambahan sel tumor melalui penekanan laluan NF- $\kappa B$. Bioaktiviti LCEO yang menjanjikan dan kuat menyokong pencalonan minyak pati ini sebagai agen antikanser.

Kata kunci: Anti-radang; GC-MS; Lantana camara; Ujian MTT

\section{INTRODUCTION}

According to the World Health Organization, cancer is the most important cause of premature deaths as it accounts for about $13 \%$ of the total death rate worldwide. This rate is increasing day by day and is expected to reach an alarming rate of 13.1 million in 2030 . $70 \%$ of the total deaths are occurring in low and middleincome countries (WHO 2014) and it has become a major health risk in most of the Asian Pacific countries (Park et al. 2008). Pakistan is the sixth most populated country in 
the world with a population of 191.71 million. In 2012, 148,000 cases of cancer were registered in Pakistan with total deaths of 101,000 . The current cancer ratio of incidences is $112 / 100,000$ with deaths $80 / 100,000$ (Ashraf \& Jamil 2016).

According to the WHO, $80 \%$ of the Earth's population is dependent on traditional medicine for the treatment of primary health issues due to the high prices of pharmaceuticals (Kim et al. 2012). Because of the safer nature and ease in availability, herbal treatment is being preferred, especially in developing countries (Gahlaut \& Chhillar 2013). Natural products from plants are renowned to be effective because they are chemically balanced and less harmful with regards to synthetic chemical agents (Asif 2015a; Asif 2015b; Rahman 2004). A large number of researchers have reported the anticancer activity of natural products and suggested their use as an anticancer agent (Badal et al. 2011; Eckelmann et al. 2016).

L. camara L., commonly known as wild or red sage, grows well at about $2000 \mathrm{~m}$ in the tropical, sub-tropical, and temperate regions of the world. The L. camara has the potential to exhibit antipyretic, antimicrobial, antidiabetic, nematicidal, antimutagenic, carminative, antispasmodic, and antirheumatic activities (Mello et al. 2005). Pharmacological investigations showed that two triterpenes, lantaninilic acid and lantoic acid isolated from aerial parts of $L$. camara possessed significant leishmanicidal potential. L. camara was also studied for anti-mycobacterial activity. It was observed that the L. camara extract in methanol furnished promising antibacterial potential comparable to rifampicin (a standard drug). In most Asian countries, its leaves are used to treat leprosy, ulcers, stomach-ache, scabies, cuts, rheumatisms, fever, asthma, hypertension, and blood pressure (Pasha et al. 2007; Verma \& Balasubramanian 2014).

Because of the considerably reported bioactivities of $L$. camara, the present study was aimed to evaluate the chemical composition, anticancer and anti-inflammatory activities of LCEO. The LCEO was obtained by steam hydro-distillation process. Its anticancer and antiinflammatory activities were evaluated using various standard assays. In this study, the LCEO was also screened for antioxidant and antimicrobial activities.

\section{MATERIALS AND METHODS}

COLLECTION AND EXTRACTION OF PLANT MATERIAL

The $L$. camara leaves were collected from the Botanical Garden of the University of Agriculture Faisalabad and were identified by a Taxonomist, Dr. Mansoor Hameed, Professor, Department of Botany, University of Agriculture Faisalabad (UAF), Faisalabad, Pakistan (voucher specimen no. 831-15-2). The fresh L. camara leaves were extracted by steam hydro-distillation using stainless steel apparatus. The collected content was filtered, dried over anhydrous sodium sulfate $(3 \mathrm{~g} / 10 \mathrm{~mL})$, and stored at $-4{ }^{\circ} \mathrm{C}$.

\section{CELL LINES, CHEMICAL, AND REAGENTS}

Human cancer cell lines i.e. HCT-116 (human colon cancer), KBM-5 (human myelogenous leukemia), U-266 (human multiple myeloma cells), MiaPaCa-2 (human pancreatic cancer cells), A-549 (human lung carcinoma cells), SCC-4 (squamous cell carcinoma) were obtained from the American Type Culture Collection. The HCT116, MiaPaCa-2, and A-549 cells were cultured in DMEM, the U-266 cells were cultured in RPMI-1640 medium, whereas KBM-5 cells were cultured in Iscove's DMEM. DMEM and RPMI media were supplemented with $10 \%$ fetal bovine serum (FBS), whereas Iscove's DMEM supplemented with $15 \%$ FBS with $1 \%$ antibiotics (100 U penicillin/mL and $100 \mathrm{mg}$ streptomycin/mL) (Gibco, USA).

Antibodies against cyclinD1, matrix mellatoproteinase-9 (MMP-9), PARP, a cellular inhibitor of apoptosis 2 (c-IAP2), Bcl-2, Bcl-xl, c-Myc, $\beta$-actin, and caspase-3 were obtained from Santa Cruz Biotechnology (USA). Survivin antibody and antibody against cellular FLICE-inhibitory protein (c-FLIP) were purchased from R \& D Systems and Imgenex (San Diego, CA, USA), respectively. Secondary antibodies i.e. POD conjugates (goat anti-rabbit and anti-mouse) were obtained from Bio-Rad (Hercules, CA, USA). Penicillin, streptomycin, DMEM, RPMI-1640, Iscove's DMEM, and fetal bovine serum were obtained from Invitrogen (USA).

\section{MTT CELL PROLIFERATION ASSAY}

The LCEO effect on the proliferation of cancer cells was determined from the dehydrogenase activity of mitochondria by MTT assay. A $5.0 \times 10^{3}$ cells $/ 0.1 \mathrm{~mL}$ cells were seeded in a 96 -well plate for $12 \mathrm{~h}$ at $37{ }^{\circ} \mathrm{C}$ in a humidified incubator in the presence of $5 \% \mathrm{CO}_{2}\left(\mathrm{CO}_{2}\right.$ Incubator, Forma Scientific, USA). Cells were treated in triplicate with 10 to $100 \mu \mathrm{g} / \mathrm{mL}$ LCEO concentrations, incubated at $37{ }^{\circ} \mathrm{C}$ for $72 \mathrm{~h}$. Then, $20 \mu \mathrm{L}$ MTT $(5 \mathrm{mg} / \mathrm{mL})$ solution was added and again contents were incubated at $37^{\circ} \mathrm{C}$ for $2 \mathrm{~h}$. Then, $100 \mu \mathrm{L}$ buffer (cell lysis) was added and incubated overnight at $37^{\circ} \mathrm{C}$. The absorbance 
was monitored at $570 \mathrm{~nm}$ using a 96-well multi-scanner (Banerjee et al. 2013). The percentage residual cell viability was determined using the relation shown in (1). Where, $\mathrm{OD}_{\mathrm{s}}$ and $\mathrm{OD}_{\mathrm{c}}$ are the absorbance values of the sample and control, respectively.

$$
\text { Cell viability }(\%)=\left[1-\frac{O D_{S}}{O D_{C}}\right] \times 100
$$

\section{TRYPAN BLUE EXCLUSION ASSAY}

Cells were treated with 25 to $100 \mu \mathrm{g} / \mathrm{mL}$ LCEO concentrations for $24 \mathrm{~h}$ at $37{ }^{\circ} \mathrm{C}$ in 96-well plates and then, isotonic trypan blue $(0.4 \%)$ was added in equal amount. After $2 \mathrm{~min}$, dye accumulated the cells, then the fraction of nonviable cell and the total number of cells were counted using a hemocytometer (FuchsRosenthal) under the light microscope (Sung et al. 2013).

\section{CLONOGENIC ASSAY}

Cells were grown and colonized by clonogenic assay. HCT-116 cells $\left(1.0 \times 10^{3}\right.$ cells per well $)$ were taken and LCEO 25 to $100 \mu \mathrm{g} / \mathrm{mL}$ concentrations were used to treat the cells, incubated at $37{ }^{\circ} \mathrm{C}$ for $48 \mathrm{~h}$. After 48 $\mathrm{h}$, the medium containing LCEO was washed off with Dulbecco's phosphate-buffered saline (PBS) and kept for 12 days for colony growth at $37{ }^{\circ} \mathrm{C}$ in an incubator $\left(5 \% \mathrm{CO}_{2}\right)$. Contents were washed with Dulbecco's PBS, then subsequently acetic acid and methanol (1:3) were added and kept for $5 \mathrm{~min}$, then washed with PBS, and stained with $0.5 \% \mathrm{CV}$ dye solution in $1: 1$ methanol and $\mathrm{H}_{2} \mathrm{O}$ for $20 \mathrm{~min}$. Finally, the content was washed with PBS, air-dried, and counted the colonies (Gupta et al. 2013).

\section{APOPTOSIS ASSAY (PLASMA MEMBRANE INTEGRITY)}

Apoptotic activity of LCEO was performed on colon cancer cells following the live/dead kit assay method. Damaged membrane cells were also studied by this method. Trials were conducted in 96-well plates. An HCT-116 cell count of $2.0 \times 10^{4} /$ well was adjusted and 25 to $100 \mu \mathrm{g} / \mathrm{mL}$ LCEO concentrations were used for cell treatment. After $24 \mathrm{~h}$, the cell washed with PBS. Cells were stained ( $5 \mu \mathrm{M}$ ethidium homodimer and $5 \mu \mathrm{M}$ calcein-AM) at room temperature for $0.5 \mathrm{~h}$ and finally, viable cells were counted (Nikon ECLIPSE TE2000-U) (Gupta et al. 2013).

\section{PROPIDIUM IODIDE (PI) STAINING (APOPTOTIC CELLS)}

KBM- 5 cells $\left(2 \times 10^{6}\right.$ cells $/ \mathrm{mL}$ of growth media $)$ were taken in 6-well plates and incubated at $37^{\circ} \mathrm{C}$ for $2 \mathrm{~h}$ and exposed to 10 to $50 \mu \mathrm{g} / \mathrm{mL}$ LCEO concentrations for 24 $\mathrm{h}$ at $37^{\circ} \mathrm{C}$. Contents were centrifuged at $2000 \mathrm{rpm}$ for $1 \mathrm{~min}$ at $4{ }^{\circ} \mathrm{C}$, then washed with PBS and re-suspend in $0.3 \mathrm{~mL}$ of PBS followed by the addition of $700 \mu \mathrm{L}$ ethanol in a drop wise manner with constant slow stirring. After ethanol mixing, the content was kept at $-20{ }^{\circ} \mathrm{C}$ for 30 min, centrifuged and the supernatant was decanted and cells were washed with PBS. The pellets obtained were resuspended in $0.5 \mathrm{~mL}$ Propidium Iodide (PI) $(1 \mathrm{mg} / \mathrm{mL}$ in PBS) and $5 \mu \mathrm{L}$ of RNAse $(1 \mu \mathrm{g} / \mathrm{mL}$ in PBS $)$. Stained cells were protected from light and analyzed (Epics XLMCL) (Li et al. 2004).

\section{WESTERN BLOT ANALYSIS}

The LCEO effect on protein expression was studied using KBM-5 cells following the previously reported method.

\section{ELECTROPHORETIC MOBILITY SHIFT ASSAY (EMSA)}

Plates (12-well) were used and KBM-5 cells $2.0 \times 10^{6}$ cells/mL were incubated for $2 \mathrm{~h}$ at $37{ }^{\circ} \mathrm{C}$ and then treated with 10 to $50 \mu \mathrm{g} / \mathrm{mL}$ concentrations of LCEO. After $8 \mathrm{~h}$ of incubation, cells were collected and washed with cold PBS. The swelling was induced by adding $10 \mu \mathrm{M}$ cold cytoplasmic extraction buffer (CEB) and kept on ice (15 min). The cytoplasmic cell fraction was lysed by adding $3.125 \mu \mathrm{L}, 10 \%$ Igepal $/ 100 \mu \mathrm{L}$ $\mathrm{CEB}$, and mixed on vortex for $20 \mathrm{~s}$. The mixture was centrifuged and pellets were mixed with $20 \mu \mathrm{M}$ cold nuclear extraction buffer. Nuclear suspensions were kept a min on ice (mixed the contents after every 5 min on vertex) and centrifuged at 10,000 rpm for $10 \mathrm{~min}$. Bradford assay (1976) was adopted for evaluation of nuclear protein concentration. For this purpose, a $15 \mu \mathrm{g}$ nuclear extract to binding buffer $(100 \mu \mathrm{M})$ was added to start the binding reaction, $2 \mu \mathrm{g}$ poly $(\mathrm{dI}: \mathrm{dC}), 3.0 \times$ $10^{5}$ counts per minute. Following this, 32P-labeled 45 mer double-stranded NF- $\kappa$ B oligo nucleotide from the human immunodeficiency virus long terminal repeat and $1 \%$ Igepal $(20 \mu \mathrm{L})$ were added in the mixture and incubated for $30 \mathrm{~min}$ at $37{ }^{\circ} \mathrm{C}$. The reaction was terminated by adding $4 \mu \mathrm{L} 6 \mathrm{X}$ DNA loading dye and the sample was placed on ice and loaded on a pre-run $6.6 \%$ polyacrylamide gel and electrophoresed. The specificity of binding of NF- $\kappa \mathrm{B}$ to the DNA was examined with double-stranded mutated oligonucleotide. Gel, thus formed was dried and analyzed (Han et al. 2004). 
LCEO GC-MS ANALYSIS

The LCEO was analyzed using an Agilent-Technologies GC-MS following a precisely reported method elsewhere (Hossain et al. 2012). The NIST 98 NIST/ EPA/NIH mass spectral library was used for compound identification.

\section{ANTIOXIDANT AND ANTIMICROBIAL ACTIVITIES}

For DPPH activity, LCEO $(0.1 \mathrm{mg} / \mathrm{mL})$ was mixed with 1 $\mathrm{mL}$ of $90 \mu \mathrm{M}$ DPPH solution and then, the final volume was made $4 \mathrm{~mL}$ by adding $95 \%$ methanol. After $1 \mathrm{~h}$ of incubation period at room temperature, the absorbance was recorded at $515 \mathrm{~nm}$ (Bozin et al. 2006). Free radical imbibition by DPPH (\%) was estimated following the relation shown in (2). Where $A_{o}$ is the OD of the control and $A_{s}$ is the OD of the sample (LCEO).

$$
\text { Inhibition }(\%)=\left[\frac{A_{0}}{A_{s}-A_{0}}\right] * 100
$$

The antimicrobial activity of LCEO was determined against a selected panel of bacterial and fungal strains i.e., Escherichia coli, Bacillus subtilis, Staphylococcus aureus, Pasteurella multocida, and Burkholderia gladioli pv gladioli (bacterial strains) and Aspergillus niger, Aspergillus flavus, Penicillium notatum, Helmenthosporium solani, and Fusarium solani (fungal strains) following the method reported elsewhere (Fritsche et al. 2007) and MIC (Sarker et al. 2007).

\section{STATISTICAL ANALYSIS}

All data were presented as mean \pm SD. Analyses of variance (ANOVA) model was used to compare the differences among more than two groups followed by a post-hoc t-test for multiple comparisons significant level was used for all tests.

\section{RESULTS AND DISCUSSION}

\section{OIL CHARACTERISTICS, ANTIOXIDANT AND ANTIMICROBIAL ACTIVITY}

The LCEO was extracted by Steam hydro-distillation and subjected to characterization and bioactivity study. The yield and physical properties of the oil are shown in Table 1. Its yield was $0.23 \mathrm{~g} / 100 \mathrm{~g}$ of fresh leaves. The refractive index was recorded to be 1.43 (at $25{ }^{\circ} \mathrm{C}$ ), whereas density was $0.83 \mathrm{~g} \mathrm{~cm}^{-3}$ (at $25^{\circ} \mathrm{C}$ ) and the color of oil was light yellow.

The LCEO was screened for antioxidant and antimicrobial activities and the results, thus obtained are given in Table 2. LCEO showed promising antimicrobial activities and comparable with standard antimicrobial agents. The zone of inhibition (ZI) against bacterial strains i.e., E. coli, B. subtilis, S. aureus, $P$. multocida and B. gladioli pv gladioli were recorded in the range of 13-16.7 mm, whereas Rifampicin showed ZI in the range of $19-22.1 \mathrm{~mm}$. The MIC values against $E$. coli, B. subtilis, S. aureus, P. multocida, and B. gladioli pv gladioli were found $10.4 \pm 0.54,9.3 \pm 0.43,7.6 \pm 0.59$, $6.3 \pm 0.41$ and $5.2 \pm 0.76(\mathrm{mg} / \mathrm{mL})$, respectively. The LCEO also showed considerable anti-fungal activities against $A$. niger, A. flavus, $P$. notatum, $H$. solani, and $F$. solani fungal strains. The ZI was recorded in the range of 17-19.1 $\mathrm{mm}$, whereas in the case of the standard anti-fungal agent (Terbinafine), the ZI was in the range of $22-27 \mathrm{~mm}$. In comparison to control, it was found that the LCEO has potential antimicrobial activities.

The antioxidant activity results of the LCEO are shown in Table 3. It was observed that LCEO also has promising antioxidant activity. The antioxidant

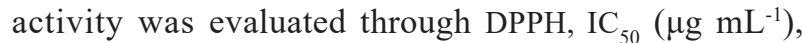
and $\beta$-carotein assay. The DPPH $\left(\mathrm{IC}_{50}\right)$ value was found to be $5.45 \pm 0.69 \mu \mathrm{g} / \mathrm{mL}$, whereas BHT showed $\mathrm{IC}_{50}$ value of $1.03 \pm 0.43 \mu \mathrm{g} / \mathrm{mL}$. The percentage inhibition of $\beta$-carotein was $78.95 \% \pm 3.18$ and was comparable with BHT $82.93 \% \pm 4.15$, which indicates that LCEO has excellent antioxidant activity.

TABLE 1. Yield and physical properties of LCEO

\begin{tabular}{cc}
\hline Parameters $^{1}$ & LCEO \\
\hline Oil yield $\left(\mathrm{g} 100 \mathrm{~g}^{-1}\right)$ & $0.23 \pm 0.02$ \\
Refractive Index $\left(25^{\circ} \mathrm{C}\right)$ & $1.43 \pm 0.08$ \\
Density $\left(\mathrm{g} \mathrm{cm}^{-3}\right),\left(25^{\circ} \mathrm{C}\right)$ & $0.83 \pm 0.02$ \\
Color of oil & Light yellow \\
\hline
\end{tabular}

${ }^{1}$ Values are mean \pm standard deviation of three samples of LCEO, analyzed individually in triplicates 
TABLE 2. Antimicrobial activity of LCEO

\begin{tabular}{|c|c|c|c|c|}
\hline \multirow{2}{*}{$\begin{array}{l}\text { Microbial strains } \\
\text { Bacterial strains }\end{array}$} & \multicolumn{2}{|c|}{ LCEO } & \multicolumn{2}{|c|}{ Standard drugs ${ }^{1}$} \\
\hline & $\mathrm{IZ}^{\mathrm{a}}$ & $\mathrm{MIC}^{\mathrm{b}}$ & $\mathrm{IZ}^{\mathrm{a}}$ & $\mathrm{MIC}^{\mathrm{b}}$ \\
\hline Escherichia coli & $13.2 \pm 0.66$ & $10.4 \pm 0.54$ & $21 \pm 0.58$ & $0.4 \pm .05$ \\
\hline Bacillus subtilis & $14 \pm 0.57$ & $9.3 \pm 0.43$ & $20 \pm 0.58$ & $0.62 \pm 0$ \\
\hline Staphylococcus aureus & $15.5 \pm 0.5$ & $7.6 \pm 0.59$ & $19 \pm 0.76$ & $0.95 \pm .18$ \\
\hline Pasteurella multocida & $16 \pm 0.76$ & $6.3 \pm 0.41$ & $21 \pm 0.86$ & $0.44 \pm .1$ \\
\hline Burkholderia gladioli pv gladioli & $16.7 \pm 0.51$ & $5.2 \pm 0.76$ & $22.1 \pm 0.75$ & $1.5 \pm 0.16$ \\
\hline Fungal strains & $\mathrm{IZ}^{\mathrm{a}}$ & $\mathrm{MIC}^{\mathrm{b}}$ & $\mathrm{IZ}^{\mathrm{a}}$ & $\mathrm{MIC}^{\mathrm{b}}$ \\
\hline Aspergillus niger & $17.4 \pm 0.87$ & $2.7 \pm 0.10$ & $20 \pm 1.53$ & $1.8 \pm 0.32$ \\
\hline Aspergillus flavus & $19.3 \pm 0.34$ & $1.9 \pm 0.07$ & $33.9 \pm 0.94$ & $0.38 \pm 0.03$ \\
\hline Penicillium notatum & $15.3 \pm 0.64$ & $3.7 \pm 0.31$ & $27 \pm 0.58$ & $0.83 \pm 0.19$ \\
\hline Helmenthosporium solani & $17.5 \pm 0.85$ & $3.1 \pm 0.27$ & $22 \pm 2.65$ & $1.5 \pm 0.12$ \\
\hline Fusarium solani & $17 \pm 0.73$ & $2.5 \pm 0.13$ & $24 \pm 1.53$ & $1.23 \pm 0.08$ \\
\hline
\end{tabular}

Values are mean \pm standard deviation of three different samples of LCEO, analyzed individually in triplicates

${ }^{\mathrm{a}} \mathrm{IZ}$, diameter of inhibition zones $(\mathrm{mm})$ including disc diameter of $6 \mathrm{~mm}$

${ }^{b} \mathrm{MIC}$, minimum inhibitory concentration $\left(\mathrm{mg} \mathrm{mL}^{-1}\right)$

${ }^{1}$ Rifampicin for bacterial and Terbinafine for fungal strains

TABLE 3. Antioxidant activity of LCEO

\begin{tabular}{ccc}
\hline Parameters $^{1}$ & LCEO & BHT \\
\hline${\text { DPPH, } \mathrm{IC}_{50}\left(\mu \mathrm{g} \mathrm{mL}^{-1}\right)}^{\% \text { Inhibition by } \beta \text {-carotein assay }}$ & $5.45 \pm 0.69$ & $1.03 \pm 0.43$ \\
\hline
\end{tabular}

${ }^{1}$ Values are mean \pm standard deviation of three samples of LCEO, analyzed individually in triplicates

\section{ANTICANCER AND ANTI-INFLAMMATORY ACTIVITIES}

To determine the LCEO anticancer activity, human cancer cell lines were used i.e., HCT-116 (colon cancer), KBM-5 (myelogenous leukemia), U-266 (multiple myeloma cells), MiaPaCa-2 (pancreatic cancer cells), A-549 (lung carcinoma cells), and SCC-4 (squamous cell carcinoma). The number of active mitochondria in the live cells is proportional to the reduction in MTT (Patil et al. 2009). The percentage inhibition was found to be concentration dependent and was maximum at $100 \mu \mathrm{g} / \mathrm{mL}$ of LCEO concentration. LCEO showed high toxic potential with a percent inhibition of 63-
$88 \%$ against all the cell lines tested (Figure 1). These findings are in line with Jonville et al. (2008) results which showed that dichloromethane L. camara leaves shown anticancer potential against fetal lung fibroblasts (WI-38). The viability of KBM-5 cells was reduced at all concentrations (up to $100 \mu \mathrm{g} / \mathrm{mL}$ ) for $24 \mathrm{~h}$ treatment. The dead cells were increased by increasing the concentration of LCEO. The LCEO showed $62.50 \%$ potential of dead cells (Figure 2). This activity of LCEO might be due to the active components present in LCEO i.e. sesquiterpenes and monoterpenes (terpinen-4-ol, D-limonene, $\alpha$-pinene, $\alpha$-humulene, and E-caryophyllene) 
(Sylvestre et al. 2005). Previously, researchers also reported an interaction of toxicity with bioactive compounds present in the extracts (Raghu et al. 2004; Taoubis et al. 1997).

The colorectal cancer cells (HCT-116) were treated with various concentrations of LCEO for $24 \mathrm{~h}$ and a live/dead cell assay was performed to determine plasma membrane integrity (red fluorescent ethidium homodimer-1) and intracellular esterase activity (green fluorescent calcein-AM). As shown in Figure 3, the highest apoptotic activity was observed at a concentration of $100 \mu \mathrm{g} / \mathrm{mL}$ LCEO with the percentage of dead cells $68.87 \%$. These findings are in line with previously reported results (Wu et al. 2014). LCEO inhibited the colony forming capability of HCT-116 cells, colonies were reduced to 15 from 887 at $100 \mu \mathrm{g} / \mathrm{mL}$, which is a good indication of anti-proliferative activity against colon cancer cells (Figure 4). These results were in agreement with other viability results obtained by MTT, Trypan blue exclusion, and apoptotic assay.

The change in cell cycle regulation was monitored to appraise the observed anti-proliferative activity of LCEO, for this flow cytometric analysis was performed and results are shown in Figure 5. It was observed that LCEO increased the apoptotic cell population in Go/G1 phase linearly to the LCEO concentration. Consequently, treatment of KBM-5 (Myelogenous leukemia) cells with LCEO resulted in cell cycle arrest and apoptosis both in Go/G1 phases.

The effects of LCEO on the expression of proteins MMP-9, Cyclin E1, XIAP, PARP, and Caspase-3 were also investigated. The LCEO also suppressed the antiapoptotic protein linearly to the LCEO concentration used (Figure 6). As the LCEO concentration increased, protein expression decreased gradually and completely down modulated at the highest concentration of 100 $\mu \mathrm{g} / \mathrm{mL}$ of LCEO. Previously, Basu and Hazra (2006) investigated that the effect of $L$. camara leaves methanolic extracts and it was observed that these extracts suppressed the expression of iNOS protein. Results showed that treatment with tested LCEO inhibited cell proliferation, which suppressed the effect of anti-apoptotic gene products in the response to exposure to LCEO and includes survivin, XIAP, cFLIP, BCL-2, and BCL-XL expressions. However, upon apoptotic stimulation cytochrome c was released from mitochondria to cytosol and this trend was in line with reported findings (Antonsson et al. 2001). Bcl-2 on the other hand is an anti-apoptotic protein, so it precludes the release of cytochrome c release from the mitochondria (Chao \& Korsmeyer 1998). The suppression of tumorcell invasion was concomitant with down-regulation of protein expression, which shows that LCEO precluded the invasion of the tumor cell and metastasis.

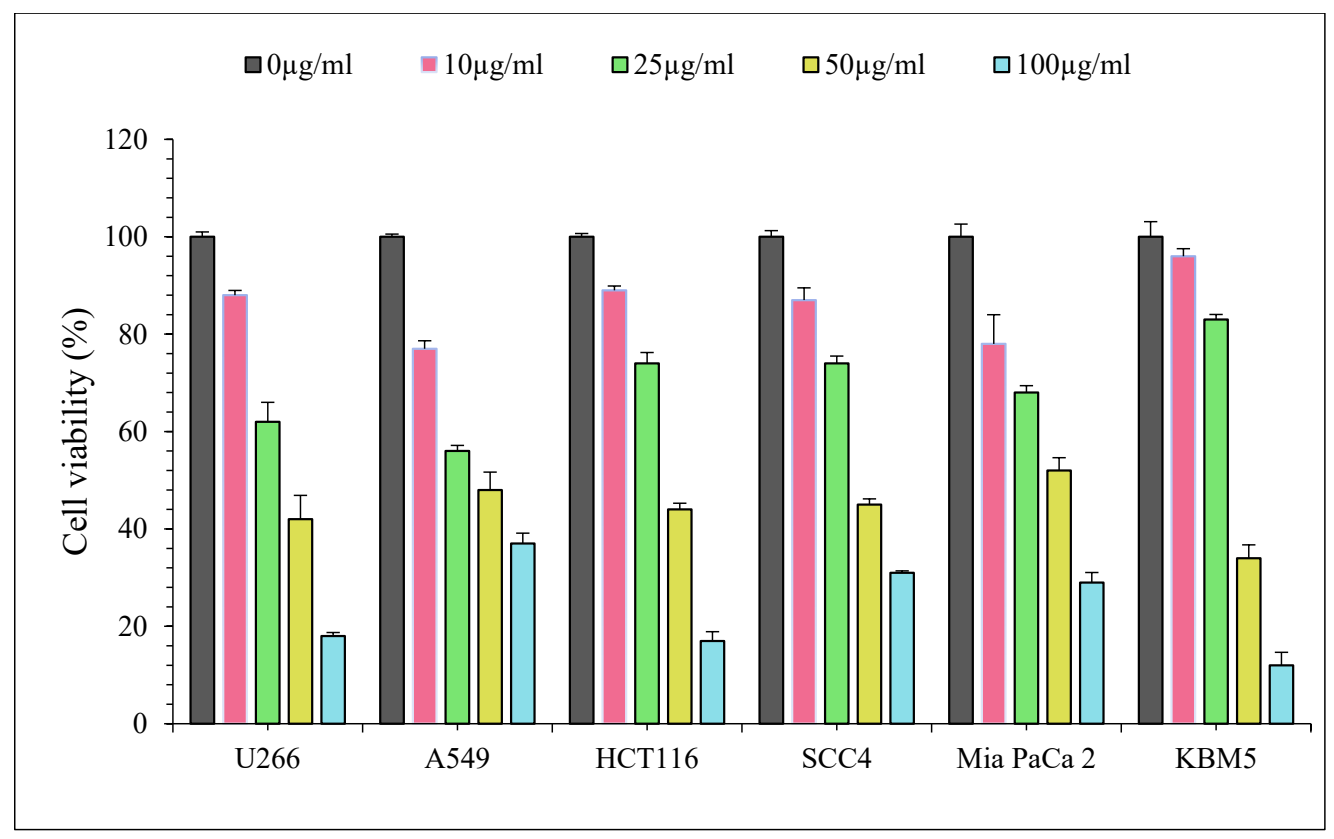

FIGURE 1. Effect of LCEO on the proliferation of tumor cell (U266, A549, HCT-116, SCC4, $\mathrm{MiaPaCa} 2$, and KBM-5). The cancer cell lines were treated in triplicates with 10 to $100 \mu \mathrm{g} /$ $\mathrm{mL}$ LCEO concentrations, incubated at $37^{\circ} \mathrm{C}$ for $72 \mathrm{~h}$ to observe the effect of LCEO on cell viability. Data represented as mean $\pm S D(\mathrm{n}=3)$ and means not sharing a common letter are significantly different for each other based on Student's t-test $(p<0.05)$ 
NF- $\mathrm{kB}$ family of transcription factor plays a key role in the regulation of all chronic diseases, NF- $\mathrm{KB}$ activation has been linked to the proliferation, survival, invasion, angiogenesis, and metastasis of different types of cancers. NF- $\mathrm{kB}$ can be activated by a wide range of inflammatory stimuli. Activation of NF- $\mathrm{kB}$ requires the activation of IKB kinase (IKK). IKK $\beta$, a subunit of the IKK complex is essential for the activation of NF- $\mathrm{KB}$ in response to various pro-inflammatory stimuli (Han et al 2014). Aberrant activation of NF-kB can be observed in cancer cells. Therefore, inhibition of NF- $\mathrm{KB}$ activation has been suggested to be a useful strategy for cancer prevention and treatment (Baldwin 2001). Most of the studies were performed using the human myeloid cell line KBM- 5 because these cells express tumor necrosis factor (TNF) receptors and the inflammatory pathways in these cells is well understood (Han et al. 2014). As it is evident from Figure 7 (EMSA results) that TNF- $\alpha$ activates the $\mathrm{NF}-\kappa \mathrm{B}$ in KBM-5 cells and pretreatment of cells with LCEO suppressed the TNF- $\alpha$-induced NF- $\mathrm{KB}$ activation in a dose-dependent manner. It was found that the inhibition in NF- $\kappa B$ activation was maximum at $50 \mu \mathrm{g} /$ $\mathrm{mL}$ dose for $8 \mathrm{~h}$ treatment. The genes involved in tumor cell survival, proliferation, invasion, and angiogenesis are all regulated by NF- $\mathrm{KB}$ (Li et al. 2004). The observed inhibition of NF-KB activation may be accounted for the down-regulation of the expression of these gene products in the response to LCEO exposure. Monoterpenes a major fraction in LCEO are known for their anti-inflammatory potential (Darland et al. 2001). The results showed that LCEO presented anticancer activities in a concentrationdependent manner and previous studies also support these findings i.e. L. camara methanol extract toxicity was evaluated on adult mice using the Vero cell line and it highly suggested the key anticarcinogenic role of L. camara. The mouse was administrated with $2 \mathrm{~g} / \mathrm{kg}$ b.w with $L$. camara leaf extract up to 14 days and then MTT assay was done. MTT assay was performed for cytotoxicity evaluation in comparison to Triton $100 \times 1 \%, 2.5$ times less toxic sign was observed for $500 \mu \mathrm{g} / \mathrm{mL}$ concentrations of leaf extract, which showed that higher concentration leaf extracts can act as pro-oxidants (Pour et al. 2011a). In another study, the L. camara toxicity (methanol extract root, stem, leaf, flower, and fruit) was investigated by brine shrimp lethality assay. The results showed that $L$. camara exhibited cytotoxicity and the author suggested the use of root extract as an anticancer agent (Pour et al. 2011b). Similarly, flowers, fruits, leaves, root, and stem cytotoxicity was also evaluated against various cell lines and the results showed that $L$. camara different parts were cytotoxic and author suggested the use of $L$. camara roots extracts to act as antitumor agent (Raghu et al. 2004). The ethnomedical data on L. camara also supported the results of the present investigation (Taoubis et al. 1997).

\section{CHEMICAL COMPOSITION OF ESSENTIAL OIL}

The study of chemical composition is important along with bioactivity valuation since the components present in the extract are responsible for bioactivities. So far, the LCEO was subjected to GC-MS analysis, and the response thus obtained is shown in Table 1. A total of 41 chemical components were detected in the LCEO representing $98.69 \%$ of the total oil fraction and the main components were oxygenated sesquiterpenes (34.23\%) and caryophyllene oxide (19.63\%). Among minor components, caryophyllene (6.68\%), $\beta$-phellandrene $(6.48 \%)$, humulene epoxide II $(5.68 \%)$, spathulenol (4.17\%), $\alpha$-pinene $(3.27 \%)$,

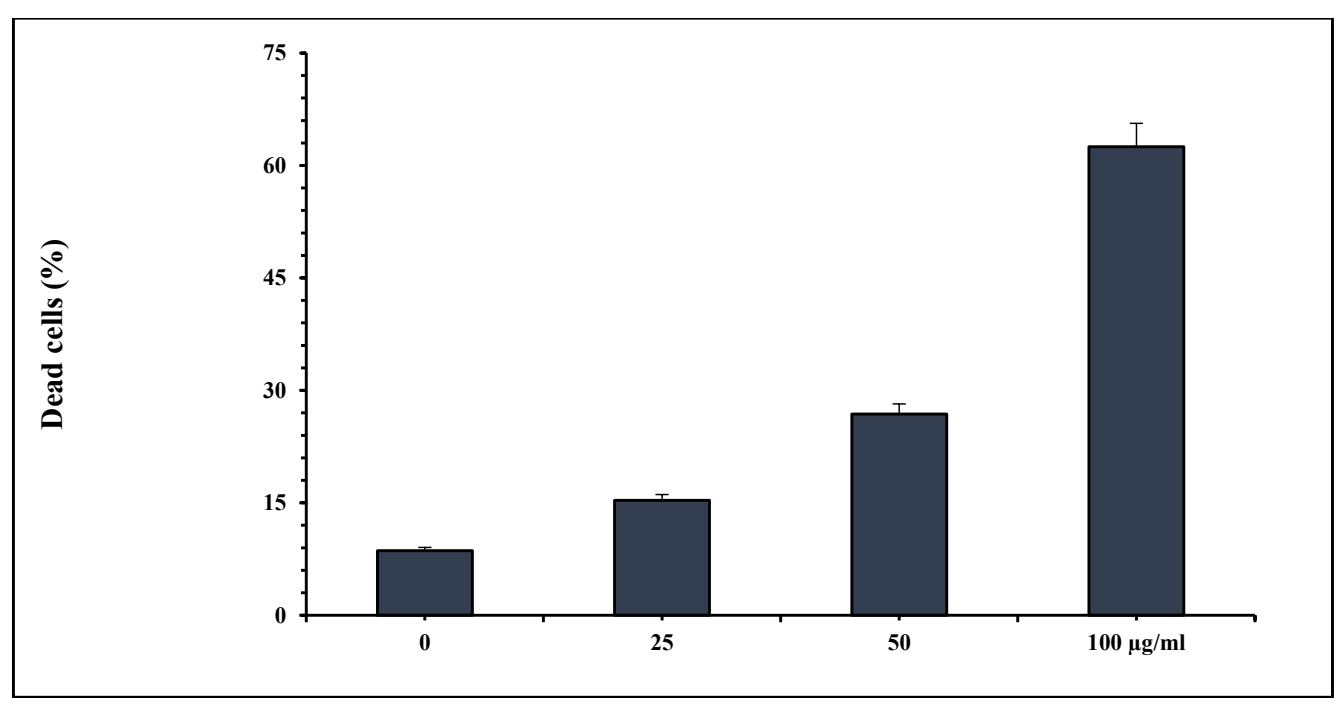

FIGURE 2. KBM5 dead cells (\%) among total cells counted treated with 0, 25, 50, and $100 \mu \mathrm{g} / \mathrm{mL}$ concentrations of LCEO for $24 \mathrm{~h}$ 
eucalyptol (3.09\%), $\alpha$-cyclocitral (2.89\%), $\beta$-pinene $(2.38 \%)$ and nerolidol II $(2.33 \%)$ along with other various minor components (Table 4). Previously, the chemical composition of L. camara grown in diverse climates in different regions is reported i.e. Saikia and Sahoo (2011) reported that LCEO was rich in oxygenated sesquiterpenes $(37.30 \%)$. In another report, Sousa et al. (2010) found that sesquiterpenes (56\%) were the main fraction in LCEO. From Iran, $\alpha$-humelene and ciscaryophyllene were the leading components in the LCEO
(Zandi-Sohani et al. 2012). The chemical composition of essential oils depending on the climate and the part of the plant used, but caryophyllene was reported to be a versatile component in LCEO. The variation in chemical composition might be due to the different agro-ecological zones and environmental conditions. Moreover, the soil condition and growing practices may also affect the chemical composition (Hairani et al. 2016; Pagliai et al. 2004) (Figure 8).
(A)

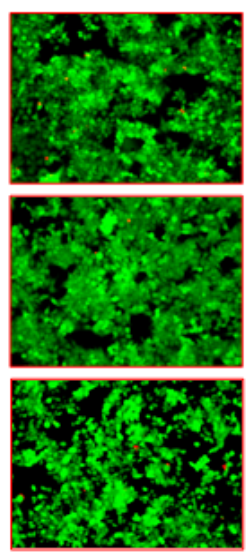

Untreated
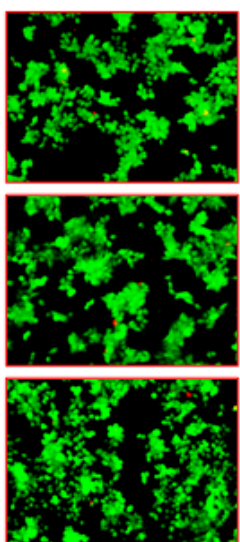

$25 \mu \mathrm{g} / \mathrm{mL}$
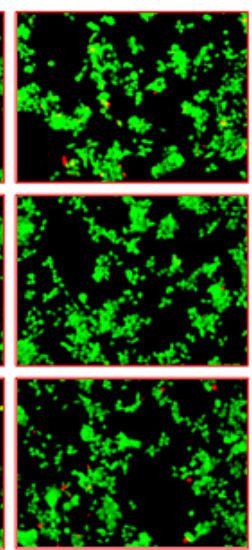

$50 \mu \mathrm{g} / \mathrm{mL}$
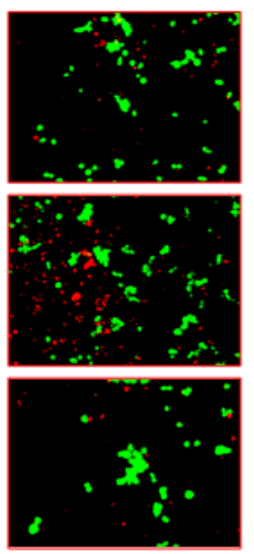

$100 \mu \mathrm{g} / \mathrm{mL}$

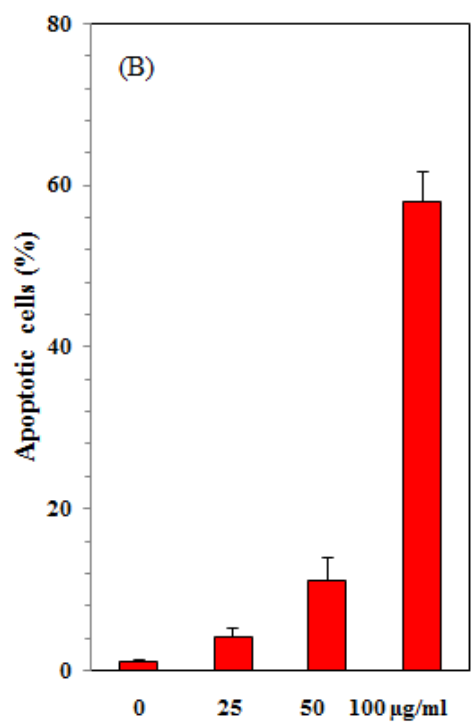

FIGURE 3. HCT-116 cells: Treated with $0,25,50$ and $100 \mu \mathrm{g} / \mathrm{mL}$ concentrations of LCEO for $24 \mathrm{~h}$

(A)

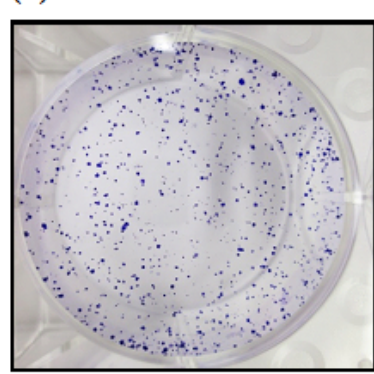

$50 \mu \mathrm{g} / \mathrm{mL}$

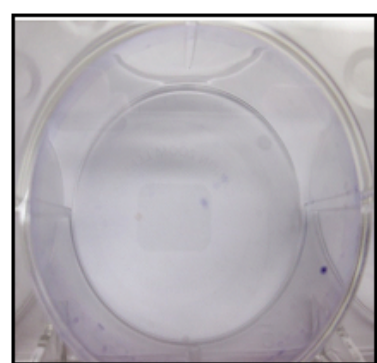

$25 \mu \mathrm{g} / \mathrm{mL}$

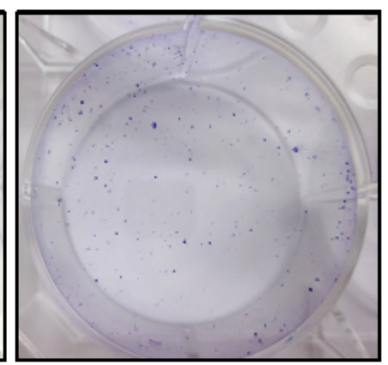

$100 \mu \mathrm{g} / \mathrm{mL}$

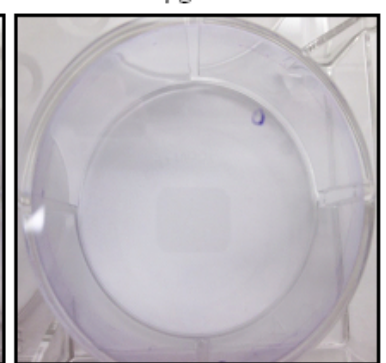

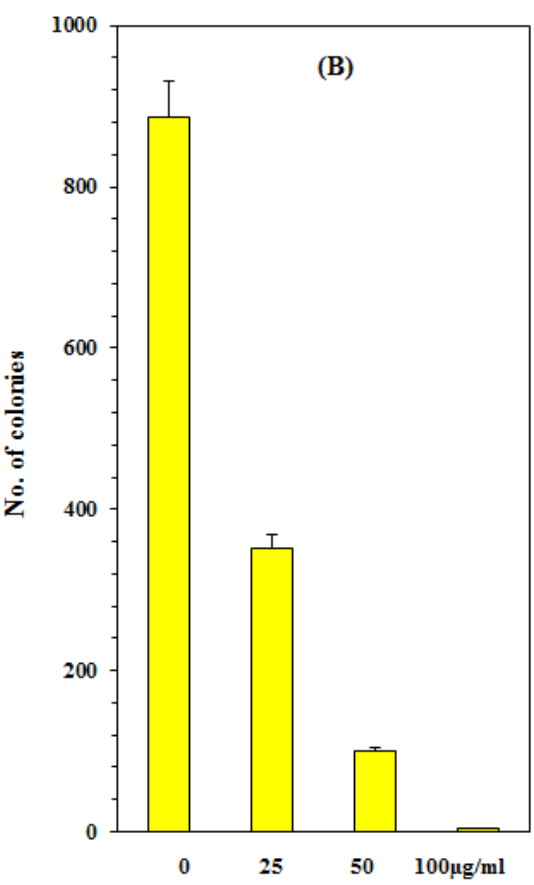

FIGURE 4. HCT-116 cells number of colonies and 6-well plates, treated with 0,25 , 50 , and $100 \mu \mathrm{g} / \mathrm{mL}$ concentrations of LCEO for $24 \mathrm{~h}$ 
Control

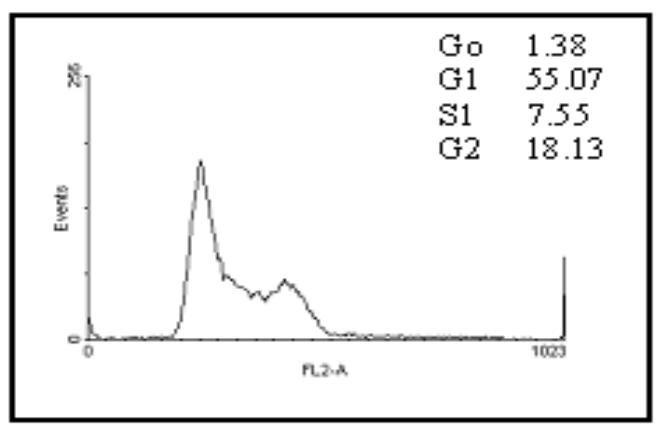

$25 \mu \mathrm{g} / \mathrm{mL}$

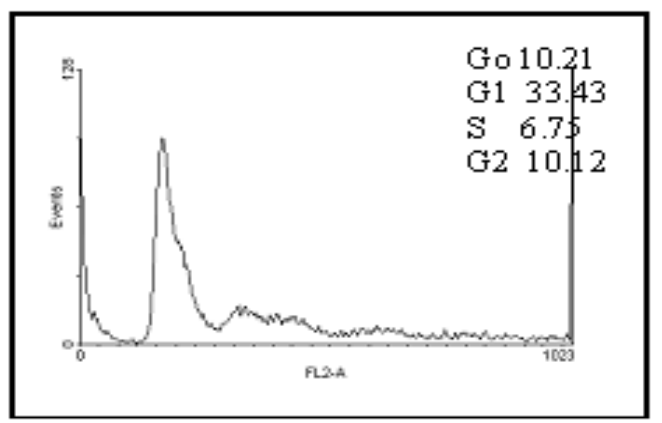

$10 \mu g / \mathbf{m L}$

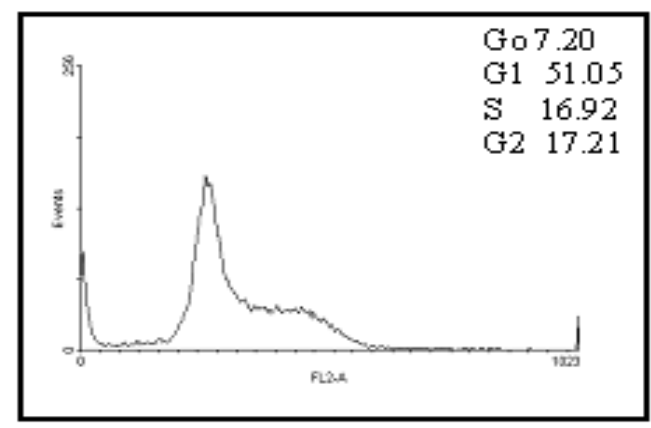

$50 \mu g / \mathbf{m L}$

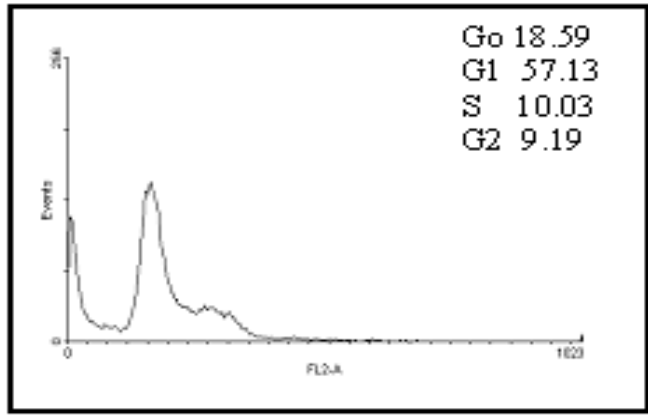

FIGURE 5. KBM-5cell cycle distribution $\left(\mathrm{G}_{\mathrm{o}} / \mathrm{G}_{1}\right.$ phase)treated with $0,10,25$, and $50 \mu \mathrm{g} / \mathrm{mL}$ concentrations of LCEO for $24 \mathrm{~h}$
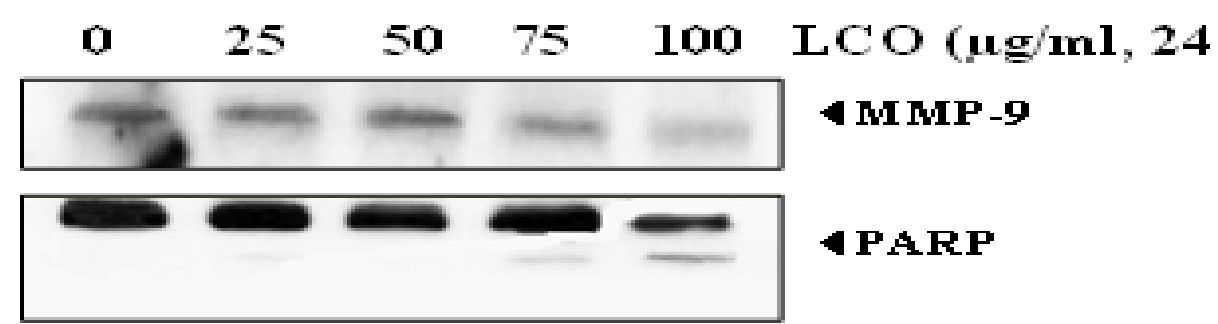

\PARP

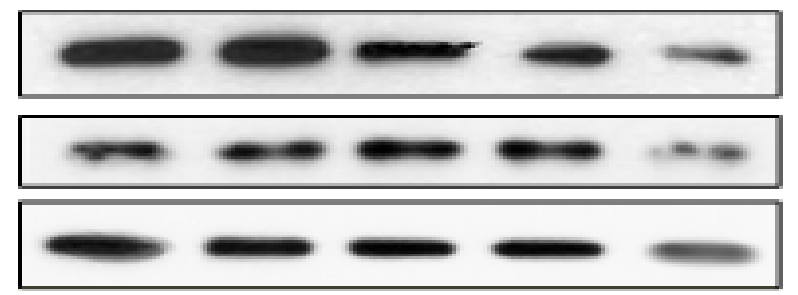

IXIAP

4 cyclin-E 1

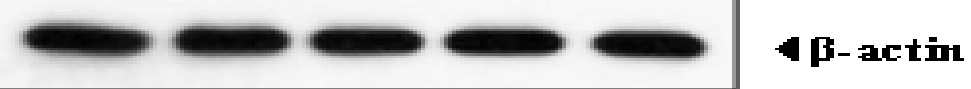

FIGURE 6. KBM-5 cells expression of gene products involved in tumor cell survival, proliferation, and metastasis, treated with $0,25,50,75$, and $100 \mu \mathrm{g} / \mathrm{mL}$ of LCEO for $24 \mathrm{~h}$ 


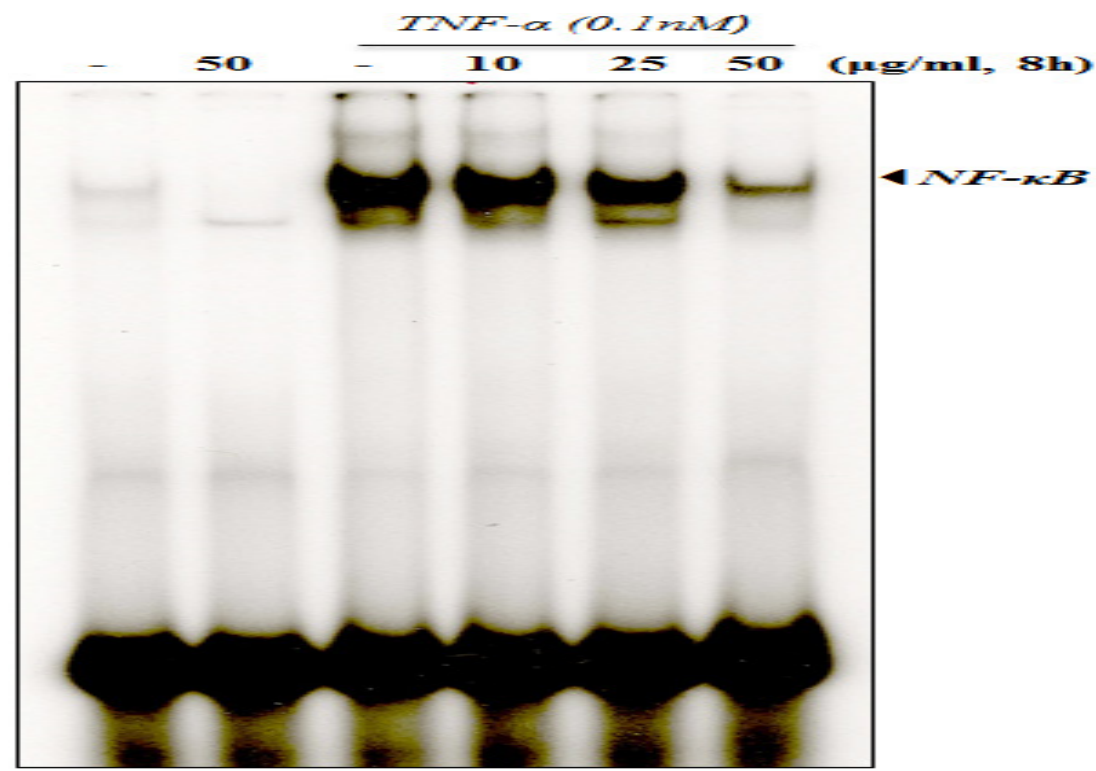

FIGURE 7. Effect of LCEO on NF- $\kappa \mathrm{B}$ cells activation, treated with $0,10,25,50$ concentration s of LCEO $\mu \mathrm{g} / \mathrm{mL}$ for $8 \mathrm{~h}$ and $0.1 \mathrm{nM}$ TNF for $30 \mathrm{~min}$

TABLE 4. Chemical composition of LCEO

\begin{tabular}{|c|c|c|}
\hline Components & Composition $(\%)$ & Retention time \\
\hline \multicolumn{3}{|l|}{ Monoterpene hydrocarbons } \\
\hline$\alpha$-Pinene & 3.27 & 9.30 \\
\hline Camphene & 1.19 & 9.78 \\
\hline$\beta$-phellandrene & 6.48 & 10.49 \\
\hline$\beta$-Pinene & 2.38 & 10.64 \\
\hline 3-Carene & 0.42 & 11.62 \\
\hline p-Cymene & 0.95 & 12.02 \\
\hline D-Limonene & 0.97 & 12.17 \\
\hline \multicolumn{3}{|l|}{ Oxygenated monoterpenes } \\
\hline 1, 8-cineole & 3.09 & 12.28 \\
\hline (E)- $\beta$-terpineol & 0.23 & 13.35 \\
\hline$(+)$-2-Bornanone & 0.35 & 15.84 \\
\hline L-4-terpineneol & 0.39 & 16.76 \\
\hline$\alpha$-Cyclocitral & 2.89 & 28.96 \\
\hline \multicolumn{3}{|l|}{ Sesquiterpene hydrocarbons } \\
\hline$\alpha$-copaene & 0.86 & 22.49 \\
\hline 8-Isopropenyl-1,5-dimethyl-cyclodeca-1,5-diene & 1.39 & 22.84 \\
\hline Caryophyllene & 6.68 & 23.75 \\
\hline$(+)$-epi-Bicyclosesquiphellandrene & 0.69 & 23.93 \\
\hline 1,4,7,-Cycloundecatriene, 1,5,9,9-tetramethyl-, Z,Z,Z- & 4.14 & 24.61 \\
\hline Alloaromadendrene & 0.24 & 24.80 \\
\hline$\gamma$-muurolene & 0.42 & 25.06 \\
\hline$\alpha$-muurolene & 0.50 & 25.63 \\
\hline Naphthalene, 1,2,4a,5,6,8a-hexahydro-4,7-dimethyl-1- & 0.60 & 26.08 \\
\hline \multicolumn{3}{|l|}{ (1-methylethyl)- } \\
\hline Humulene & 0.54 & 28.20 \\
\hline
\end{tabular}


Bicyclo[4.4.0]dec-1-ene, 2-isopropyl-5-methyl-9-

methylene-

Oxygenated sesquiterpenes

NerolidolII $\quad 2.33$

26.98

Davanone

27.22

(-)-Spathulenol

Caryophyllene oxide

27.92

Humulene epoxide II

28.49

$\alpha$-Santalol

29.46

trans-Z- $\alpha$-Bisabolene epoxide

29.76

13 3-trimethyl-2-hydroxymethyl-3 3-dimethyl-4-(3-

methylbut-2-enyl)-cyclohexane

19.63

5.68

0.39

0.64

30.54

Others

3-Methylpentane

Hexane

Methylcyclopentane

Isovaleric acid

a-terpinyl acetate

[1,2,4]Triazolo[1,5-a]pyrimidine-6-carboxylic acid,

7-amino-, ethyl ester

Spiro[2.4]heptane-5-methanol, 5-hydroxy-

Bicyclo[10.1.0]tridec-1-ene

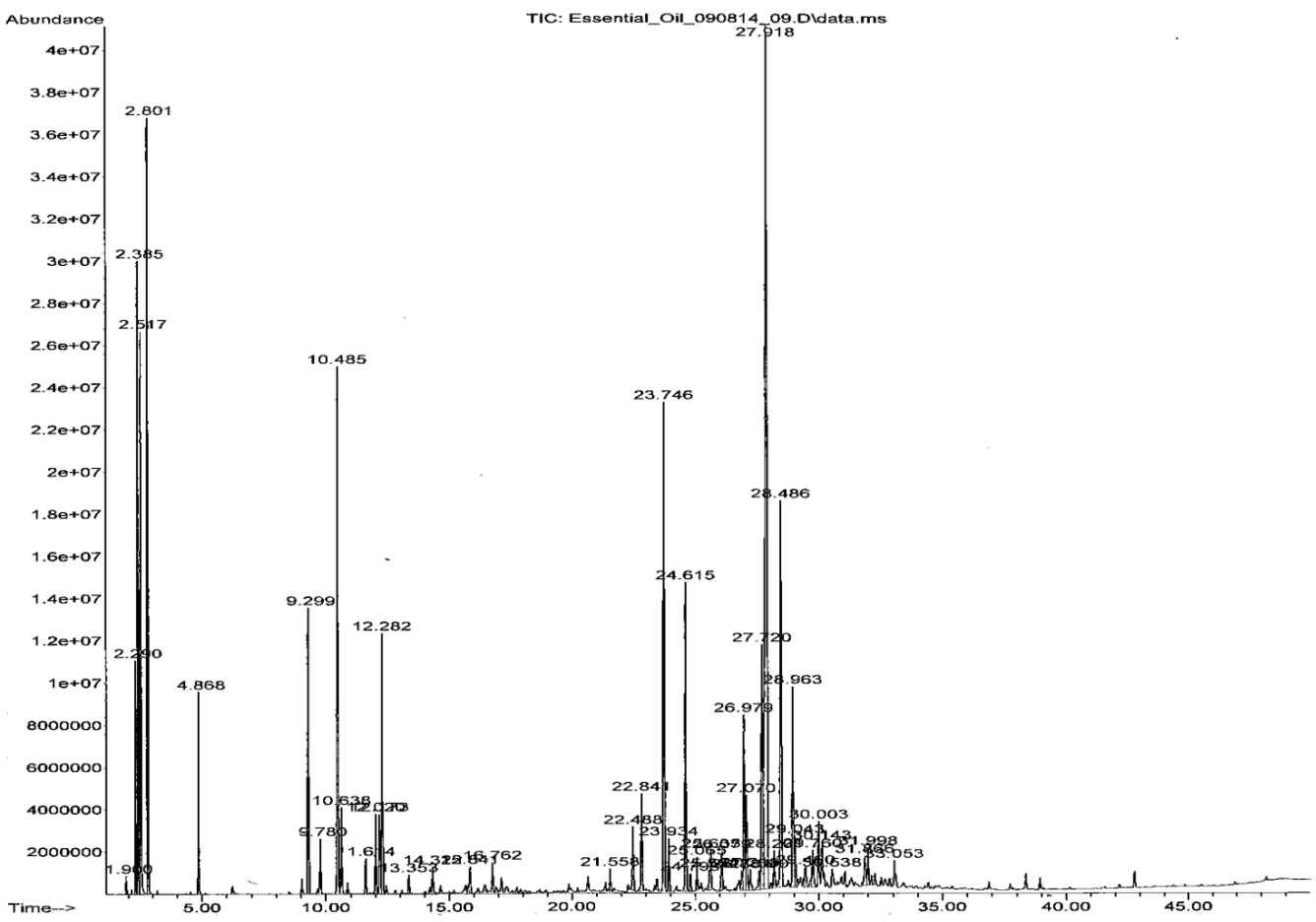

FIGURE 8. GC-MS profile chromatogram of L. camara leaves essential oil 


\section{CONCLUSION}

Anticancer and anti-inflammatory activities along with the chemical composition of LCEO were evaluated. The antimicrobial and antioxidant activities were also studied. Steam hydro-distillation yielded a good yield of LCEO and extracted oil was found to have considerable antioxidant and antimicrobial activities. The major components in LCEO were caryophyllene oxide, caryophyllene, $\beta$-phellandrene, humulene epoxide II, spathulenol, $\alpha$-pinene, eucalyptol, $\alpha$-cyclocitral, $\beta$-pinene, and nerolidol II. The LCEO showed promising activity against U-266, A-549, HCT-116, SCC-4, MiaPaCa 2, and KBM-5 cancer cell lines along with the excellent anti-inflammatory activity. The promising bioactivities support the candidature of LCEO as a potent source of anticancer agent. However, more studies are required to identify the main component responsible for bioactivity.

\section{ACKNOWLEDGEMENTS}

The authors are grateful to the Higher Education Commission Islamabad, Pakistan, for providing the grant to conduct this research and Dr. B.B. Aggarwal for providing facilities to carry out this research work in his Cytokine Research Laboratory, Department of Experimental Therapeutics, MD Anderson Cancer Center, Houston, Texas, USA.

\section{REFERENCES}

Antonsson, B., Montessuit, S., Sanchez, B. \& Martinou, J.C. 2001. Bax is present as a high molecular weight oligomer/ complex in the mitochondrial membrane of apoptotic cells. Journal of Biological Chemistry 276(15): 1161511623.

Ashraf, M.S. \& Jamil, A. 2016. Cancer care in Pakistan. In Cancer Care in Countries and Societies in Transition, edited by Silbermann, M. Springer, Cham. https://doi. org/10.1007/978-3-319-22912-6_15.

Asif, M. 2015a. Pharmacologically potentials of different substituted coumarin derivatives. Chemistry International 1(1): 1-11.

Asif, M. 2015b. Chemistry and antioxidant activity of plants containing some phenolic compounds. Chemistry International 1(1): 35-52.

Badal, S., Williams, S.A., Huang, G., Francis, S., Vedantam, P., Dunbar, O., Jacobs, H., Tzeng, T.J., Gangemi, J. \& Delgoda, R. 2011. Cytochrome P450 1 enzyme inhibition and anticancer potential of chromene amides from Amyris plumieri. Fitoterapia 82(2): 230-236. doi: 10.1016/j. fitote.2010.10.003.

Baldwin, A.S. 2001. Series introduction: The transcription factor NF- $\mathrm{kB}$ and human disease. The Journal of Clinical Investigation 107(1): 3-6. doi.org/10.1172/JCI11891.
Banerjee, A., Dahiya, M., Anand, M.T. \& Kumar, S. 2013. Inhibition of proliferation of cervical and leukemic cancer cells by penicillin G. Asian Pacific Journal of Cancer Prevention 14(1): 2127-2130. doi:10.7314/ APJCP.2013.14.3.2127.

Basu, S. \& Hazra, B. 2006. Evaluation of nitric oxide scavenging activity, in vitro and ex vivo, of selected medicinal plants traditionally used in inflammatory diseases. Phytotherapy Research 20(10): 896-900.

Bozin, B., Mimica-Dukic, N., Simin, N. \& Anackov, G. 2006. Characterization of the volatile composition of essential oils of some Lamiaceae spices and the antimicrobial and antioxidant activities of the entire oils. Journal of Agricultural and Food Chemistry 54(5): 1822-1828. doi. org/10.1021/jf051922u.

Bradford, M.M.A. 1976. rapid and sensitive method for the quantitation of microgram quantities of protein utilizing the principle of protein-dye binding. Analytical biochemistry 72(1-2): 248-254.

Chao, D.T. \& Korsmeyer, S.J. 1998. BCL-2 family: Regulators of cell death. Annual Review of Immunology 16(1): 395419.

Darland, G.K., Lukaczer, D.O., Liska, D.J., Irving, T.A. \& Bland, J.S. 2001. U.S. Patent No. 6,210,701. Washington, DC: U.S. Patent and Trademark Office.

Eckelmann, D., Kusari, S. \& Spiteller, M. 2016. Occurrence and spatial distribution of maytansinoids in Putterlickia pyracantha, an unexplored resource of anticancer compounds. Fitoterapia 113: 175-181.

Fritsche, T.R., McDermott, P.F., Shryock, T.R. \& Walker, R.D. 2007. Agar dilution and disk diffusion susceptibility testing of Campylobacter spp. Journal of Clinical Microbiology 45(8): 2758-2759. doi: 10.1128/JCM.0056907.

Gahlaut, A. \& Chhillar, A.K. 2013. Evaluation of antibacterial potential of plant extracts using resazurin based microtiter dilution assay. International Journal of Pharmacy and Pharmaceutical Sciences 5(2): 372-376.

Gupta, R.K., Sharma, G., Pandey, R., Kumar, A., Koch, B., Li, P.Z. \& Pandey, D.S. 2013. DNA/protein binding, molecular docking, and in vitro anticancer activity of some thioether-dipyrrinato complexes. Inorganic Chemistry 52(24): 13984-13996. doi.org/10.1021/ ic401662.

Hairani, A., Osaki, M. \& Watanabe, T. 2016. Effect of biochar application on mineral and microbial properties of soils growing different plant species. Soil Science and Plant Nutrition 62(5-6): 519-525. doi:10.1080/00380768.201 6.1212648 .

Han, J.G., Gupta, S.C., Prasad, S. \& Aggarwal, B.B. 2014. Piperlongumine chemosensitizes tumor cells through interaction with cysteine 179 of IкB $\alpha$ kinase, leading to suppression of NF- $\kappa \mathrm{B}$-regulated gene products. Molecular Cancer Therapeutics 13(10): 24222435. doi: 10.1158/1535-7163.mct-14-0171.

Han, M., Wen, J.K., Zheng, B. \& Zhang, D.Q. 2004. Acetylbritannilatone suppresses NO and PGE2 synthesis in RAW 264.7 macrophages through the inhibition of 
iNOS and COX-2 gene expression. Life Sciences 75(6): 675-684. doi.org/10.1016/j.lfs.2003.12.022.

Hossain, M.A., Al-Hashmi, R.A., Weli, A.M., Al-Riyami, Q. \& Al-Sabahib, J.N. 2012. Constituents of the essential oil from different brands of Syzigium caryophyllatum L. by gas chromatography-mass spectrometry. Asian Pacific Journal of Tropical Biomedicine 2(3): S1446-S1449. doi. org/10.1016/S2221-1691(12)60435-3.

Jonville, M.C., Kodja, H., Humeau, L., Fournel, J., De Mol, P., Cao, M. \& Frederich, M. 2008. Screening of medicinaol plants from Reu Island for antimalarial and cytotoxic activity. Journal of Ethnopharmacology 120(3): 382-386. doi.org/10.1016/j.jep.2008.09.005.

Kim, J.H., Gupta, S.C., Park, B., Yadav, V.R. \& Aggarwal, B.B. 2012. Turmeric (Curcuma longa) inhibits inflammatory nuclear factor (NF)- $\kappa B$ and NF- $\mathrm{NB}$-regulated gene products and induces death receptors leading to suppressed proliferation, induced chemosensitization, and suppressed osteoclastogenesis. Molecullar Nutrition and Food Research 56(3): 454-465. doi: 10.1002/ mnfr.201100270.

Li, L., Aggarwal, B.B., Shishodia, S., Abbruzzese, J. \& Kurzrock, R. 2004. Nuclear factor- $\kappa \mathrm{B}$ and $\mathrm{I} \kappa \mathrm{B}$ kinase are constitutively active in human pancreatic cells, and their down-regulation by curcumin (diferuloylmethane) is associated with the suppression of proliferation and the induction of apoptosis. Cancer 101(10): 2351-2362. doi. org/10.1002/cncr.20605.

Mello, F.B., Jacobus, D., Carvalho, K. \& Mello, J.R. 2005. Effects of Lantana camara (Verbenaceae) on general reproductive performance and teratology in rats. Toxicon 45(4): 459-466. doi:10.1016/j. toxicon.2004.12.004.

Pagliai, M., Vignozzi, N. \& Pellegrini, S. 2004. Soil structure and the effect of management practices. Soil and Tillage Research 79(2): 131-143. doi.org/10.1016/j. still.2004.07.002.

Park, S., Bae, J., Nam, B.H. \& Yoo, K.Y. 2008. Aetiology of cancer in Asia. Asian Pacific Journal of Cancer Prevention 9(3): 371-380.

Pasha, C., Nagavalli, M. \& Venkateswar, V.L. 2007. Lantana camara for fuel ethanol production using thermotolerant yeast. Letters in Applied Microbiology 44(6): 666-672.

Patil, J.R., Jayaprakasha, G.K., Murthy, K.C., Tichy, S.E., Chetti, M.B. \& Patil, B.S. 2009. Apoptosis-mediated proliferation inhibition of human colon cancer cells by volatile principles of Citrus aurantifolia. Food Chemistry 114(4): 1351-1358. doi.org/10.1016/j.foodchem.2008.11.033.

Pour, B.M., Latha, L.Y. \& Sasidharan, S. 2011a. Cytotoxicity and oral acute toxicity studies of Lantana camara leaf extract. Molecules 16(5): 3663-3674. doi.org/10.3390/ molecules 16053663 .

Pour, B.M. \& Sasidharan, S. 2011b. In vivo toxicity study of Lantana camara. Asian Pacific Journal of Tropical Biomedicine 1(3): 230-232. doi: 10.1016/S22211691(11)60033-6.
Raghu, C., Ashok, G., Dhanaraj, S.A., Suresh, B. \& Vijayan, P. 2004. In vitro cytotoxic activity of Lantana camara Linn. Indian Journal of Pharmacology 36(2): 94-95.

Rahman, Ì. 2004. Brine shrimp toxicity of leaf and seed extracts of Cassia alata Linn, and their antibacterial potency. Journal of Medical Science 4(3): 188-193.

Saikia, A.K. \& Sahoo, R.K. 2011. Chemical composition and antibacterial activity of essential oil of Lantana camara L. Middle-East Journal of Scientific Research 8(3): 599602.

Sarker, S.D., Nahar, L. \& Kumarasamy, Y. 2007. Microtitre plate-based antibacterial assay incorporating resazurin as an indicator of cell growth, and its application in the in vitro antibacterial screening of phytochemicals. Methods 42(4): 321-324. doi.org/10.1016/j. ymeth.2007.01.006.

Sousa, E.O., Silva, N.F., Rodrigues, F.F., Campos, A.R., Lima, S.G. \& Costa, J.G.M. 2010. Chemical composition and resistance-modifying effect of the essential oil of Lantana camara Linn. Pharmacognosy Magazine 6(22): 79-82. doi: 10.4103/0973-1296.62890.

Sung, B., Prasad, S., Yadav, V.R., Gupta, S.C., Reuter, S., Yamamoto, N. \& Aggarwal, B.B. 2013. RANKL signaling and osteoclastogenesis is negatively regulated by cardamonin. PLoS ONE 8(5): e64118.

Sylvestre, M., Legault, J., Dufour, D. \& Pichette, A. 2005. Chemical composition and anticancer activity of leaf essential oil of Myrica gale L. Phytomedicine 12(4): 299-304. doi.org/10.1016/j.phymed.2003.12.004.

Taoubis, K., Fauvel, M.T., Gleye, J., Moulis, C. \& Fouraste, I. 1997. Phenylpropanoid glycosides from Lantana camara and Lippia multiflora. Planta Medica 63(2): 192-193.

Verma, V. \& Balasubramanian, K. 2014. Experimental and theoretical investigations of Lantana camara oil diffusion from polyacrylonitrile membrane for pulsatile drug delivery system. Materials Science and Engineering: C 41: 292-300.

World Health Organization (WHO). 2014. Global Status Report on Alcohol and Health.

Wu, P., Wu, D., Ni, C., Ye, J., Chen, W., Hu, G. \& Chen, Z. 2014. $\gamma \delta$ T 17 cells promote the accumulation and expansion of myeloid-derived suppressor cells in human colorectal cancer. Immunity 40(5): 785-800. doi.org/10.1016/j. immuni.2014.03.013.

Zandi-Sohani, N., Hojjati, M. \& Carbonell-Barrachina, Á.A. 2012. Bioactivity of Lantana camara L. essential oil against Callosobruchus maculatus (Fabricius). Chilean Journal of Agricultural Research 72(4): 502-506. doi.org/10.4067/ S0718-58392012000400007.

Arfaa Sajid \& Qaisar Manzoor

Department of Chemistry

The University of Lahore, Lahore

Pakistan 
Anam Sajid

Department of Chemistry

University of Punjab, Lahore

Pakistan

Muhammad Imran

University Institute of Diet and Nutritional Sciences

Faculty of Allied Health Sciences

The University of Lahore-Lahore

Pakistan

Farhan Aslam

Department of Food Science and Human Nutrition

University of Veterinary and Animal Sciences, Lahore

Pakistan

Tanweer Aslam Gondal

School of Exercise and Nutrition

Deakin University

Victoria 3221

Australia
Rabia Shabir Ahmad, Muhammad Umair Arshad \& Ali Imran* Institute of Home \& Food Sciences

Government College University, Faisalabad

Pakistan

Ghulam Hussain

Neurochemicalbiology and Genetics Laboratory (NGL)

Department of Physiology, Faculty of Life Sciences

Government College University

Faisalabad, 38000

Pakistan

*Corresponding author; email: aliimran.ft@gmail.com

Received: 18 June 2020

Accepted: 15 February 2021 